[Note]

\title{
Identification of Mites and Establishment of Screening Method in Ear Canker of Rabbits
}

\author{
Akio MATSUZAWA, Kazuo OKADA, Etsuro MOTOI, Kiyoshi SUZUKI \\ and Susumu MUTO \\ Laboratory Animal Research Center, Institute of Medical Science, \\ University of Tokyo, P.O. Takanawa, Tokyo 108
}

\begin{abstract}
Ear canker has occurred in many rabbits in a laboratory animal center for the past several years. Attempting to develop effective therapeutic and prophylactic measures, the present observation was conducted to identify mites causing the disease and to devise a very simple and rapid method for collecting them by the aid of adhesive vinyl tape from affected cymba conchae and basis conchae. The following results were obtained: (1) The mites collected were identified as Psoroptes cuniculi (Delafond 1958). (2) Mites were demontrated by the mite adhering test in 20 rabbits showing no macroscopic signs of ear canker. (3) Of a total number of 216 rabbits examined $75(34.7 \%)$ were diagnosed as ear canker by this test and macroscopic observation.-Exp. Animals, 23(2), 73-77, 1974.
\end{abstract}

\section{ウサギ耳疥癖症原因ダニの同定および検査法}

\author{
松沢昭雄・岡田和夫・元井悦郎・鈴木 潔・武藤 進 \\ 東京大学医科学研究所実験動物研究施設
}

実験用ウサギに耳疥編症 (ear canker) が相当広く蔓 延している。それにあかかわらず，発症初期は耳介内梁 部のため目につき難く, また本症は動物の健康や生命に 直接関係ないため, 病巣が拡がり, 外耳口から外に現わ れて始めて気付くのが現実である。てのように病気が進 行してしまってから，急いでウサギを淘汰してあ，ダニ が周囲のウサギにまで拡がってしまっていて手遅れであ る。たとえ, ウサギが健康そうにみえてあ, ダ二が寄生 し吸血すると瘦㾕感を惹き起し, 動物を非常に不安定に する。さらに，吸血による傷が二次感染の原因となった り，ダ二が他の病気を媒介したりするのみならず，ダ二 が内耳樑部や脳まで犯し動物の生命を奪うこともある。 「きれいな実験動物」の開発が広く叫ばれている現在, ダニの寄生は全く好ましくないととは明らかである。

本症の重要性㹥本症があらゆる成書 $[1,3,4,5]$ で取り 挙げられているととから，そしてその治療撲滅の困難さ は20年以上屯前に行われた井上・野坂 [6]による治療実 験が唯一の報告であるととから，明らかである。との報
告も，本症の治療のためには，現在ではほとんど役立た ない。

当施設でも過去数年にわたり飼育中のウサギに本症が 蔓延し，その対策に悩まされてきた。そてで本症の治療 撲滅を企て, 一連の研究を行っている。その基礎的研究 として, ウサギに寄生しているダニの同定およびダニが 肉眼的病巣を形成する以前にダ二の寄生の有無を検査で きる簡単なスクリーニング法の確立を試みた。以下に得 られた結果を報告する。

材料および方法：動物：当施設で飼育管理中の $216 匹$ の雌雄ウサギ (市販日本白色種, New Zealand White 種 を若干含む）を対象として行った。乙れらのウサギは研 究者が実験使用中のものである。

ダ二標本の作成法 : 本症のひどいウサギの耳介内の病 巣をピンセットで剝ぎ取り，飽和食塩水に浸す。表面に 浮上したダ二（成虫, 幼虫, 卵) を双眼解剖顕微鏡下で ( $\times 25 \sim 40)$ 針で拾い上げ, 前以ってスライドグラス上に 滴下して扔いた 1 滴のガムクロラール上にのせる。ダニ 


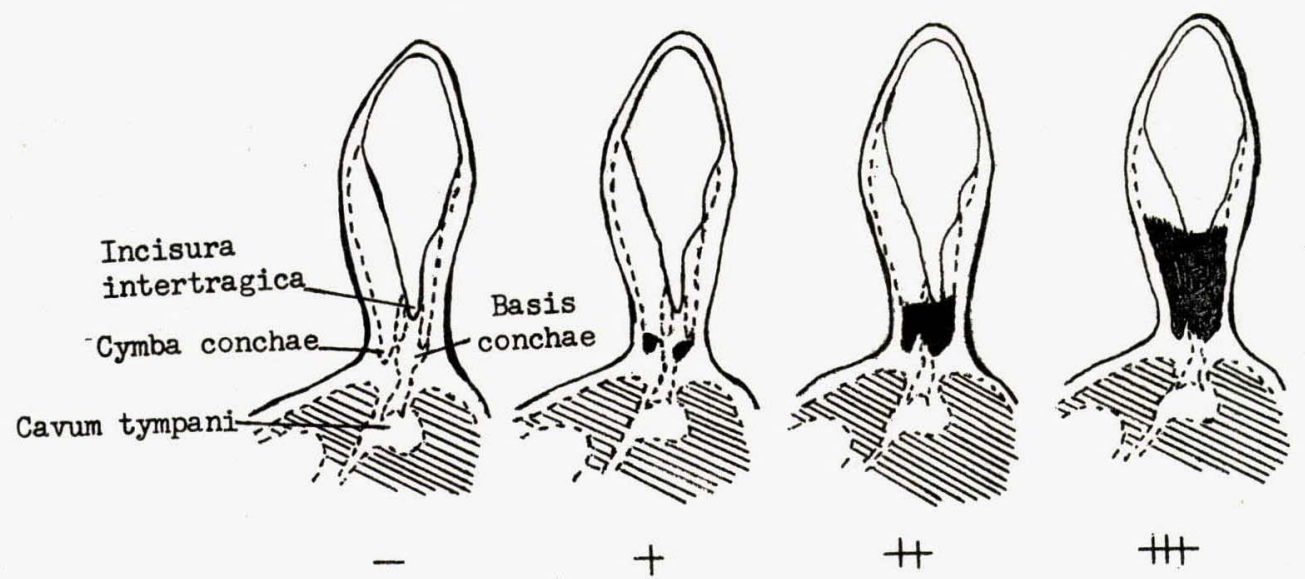

Figure 1. Criteria for grading the macroscopic finding in rabbit canker. - : No abnormalities were found anywhere inside of the auricle. + : Early pathologic change or a lot of dirt was found in cymba conchae and/or basis conchae. ++ : Scabbed and cankered area was observed, but restricted under the level of incisura intertragica. And +++ : Severe canker occurred, and the scabbeb and cankered area extended beyond the level of incisura intertragica.
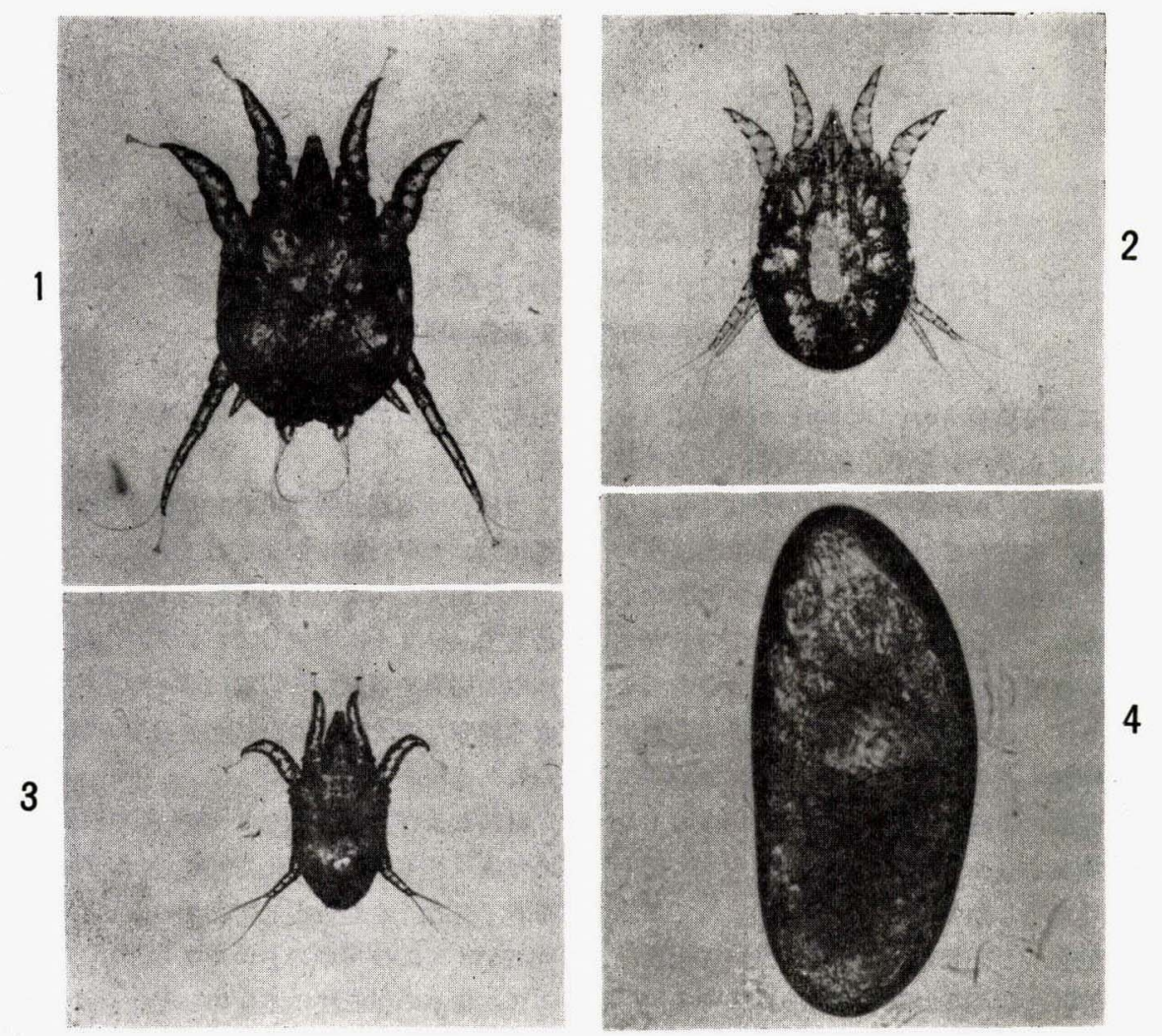

Photo 1. Psoroptes cuniculi, abult male

Photo 2. P. cuniculi, adult female.

Photo 3 P. cuniculi, larva.

Photo 4. P. cuniculi, egg with a growing embryo. 

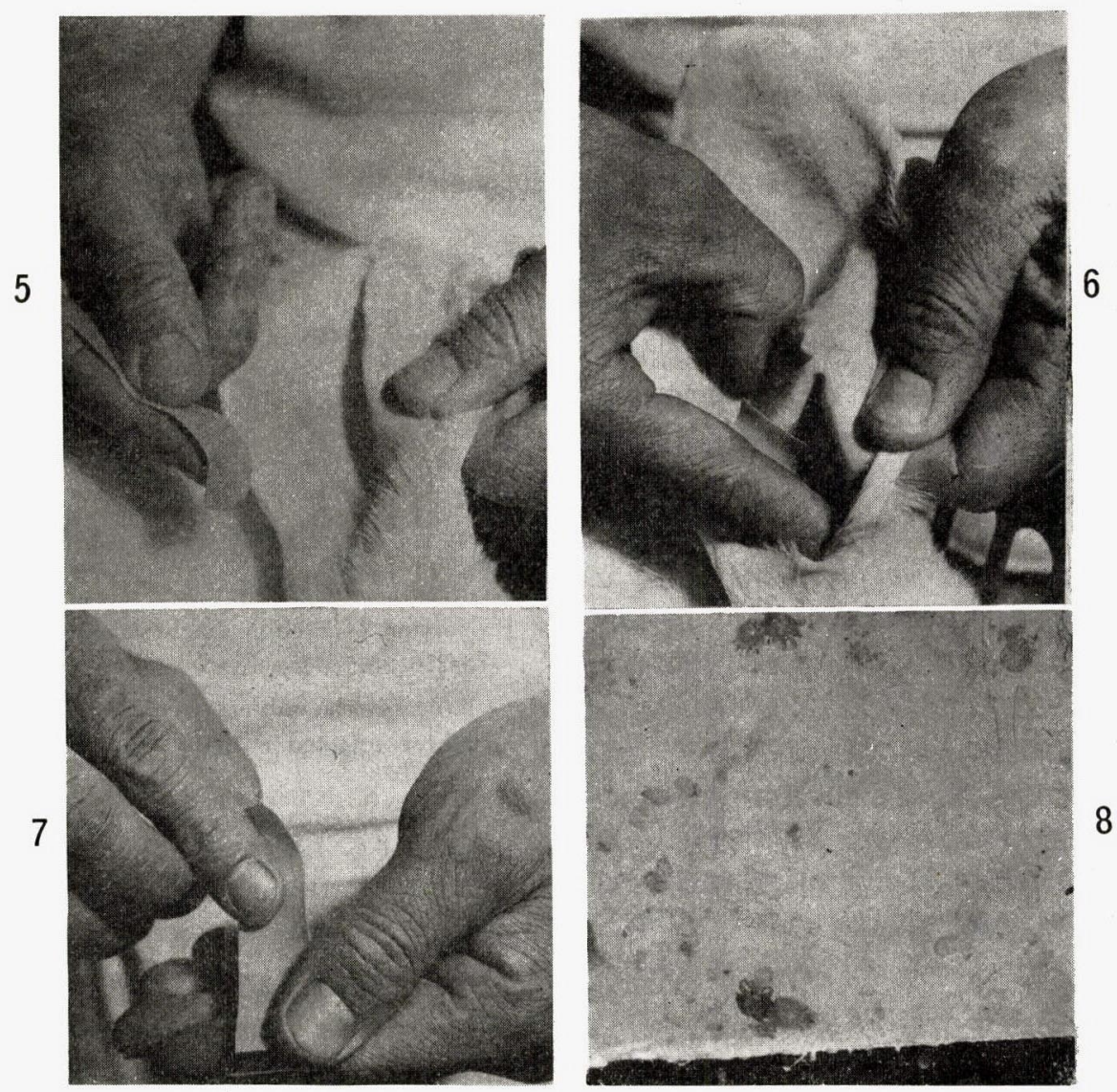

Photos 5-8. Explanation of the techique how to carry out mite adhering test. Hold a piece of adhesive vinyl tape ( $19 \mathrm{~mm}$ in width and approximately $70 \mathrm{~mm}$ in length) by the thumb and the forefinger keeping the adhesive surface external as shown in Photo 5. Insert the tape into the deep part of the auricle and adhere it to cymba conchae securely (Photo 6). Thentake it off and stick it on slide glass (Phote 7), followed by observation under stereomicroscope at a magnification of $30-80$. Photo 8 shows mites collected by this technique.

の位置姿勢を正し，沈むのを待ち静かにカバーグラスを かける。ガムクロラールは佐々等の方法 [9]により調製 した。完成した標本を顕微鏡下 $(\times 40 \sim 200)$ で観察し, 同定した。

肉眼的観察：全ウサギの耳介内を肉眼で観察し，本症 の発症の有無を確かめた。病巣の拡大の程度を四 1 亿示 す基準により，4段階，一，十，H，\#に分け，肉眼所 見とした。

ダ二の検査法 : 耳介内深部に寄生しているダ二を直接 肉眼でみつけたり, ピンセット, 筆などの器具により採 集することは困難であった。そこで，接着テープによる 蟯虫の集団㭘查にヒントを得て, ダニを接着テープで採 集するととにした。セロテープ, 両面テープ, ビニール テープ（無色透明, 白, 赤, 青, 黄) を使用して試験し た。これらのテープを耳甲介艇に密着させた後に剝ぎ取 り，スライドグラスに貼り付けて，双眼解剖顕微鏡下で
テープの状態およびダ二の採集状況を観察した。

成績：ダ二の固定：ウサギの疥䬺症の原因ダ二とし て, Psoroptes cuniculi (Delafond 1859) (ウサギキュ ウセンヒゼンダニ), Notoedres cuniculi (Gerlach 1857) (ウサギショウセンコウヒゼンダニ) および Chorioptes cuniculi (Zurn 1874) (ウサギショクヒヒゼンダニ)の 3 種類が報告されている〔4]。得られたダ二を，これらの ダニのそれぞれの特徴と比較検討した。写真 1 および 2 に示すごとく, 各脚端に関節状の区分のある長い柄のつ いた肉盤（ただし，雌は第 3 脚に肉盤を欠き，その代り に2 本の剛毛をあっている）をもつことを有力な根拠と して, 無気門亜目 (Suborder Sarcoptiformes), ヒゼ ンダニ団 (Cohert Psoroptida)，キュウセンヒゼンダニ 科 (Family Psoroptidae), キュウセンヒゼンダニ科 (Genus Psoroptes), ウサギキュウセンヒゼンダニ (Psoroptes cuniculi) と同定した。 
Psoroptes cuniculi (写真1-4) は次の特徵をむってい る。体形は卵形または卵円形で，吻は長円錐形，第 1 ， 2 脚は大きくがっしりとし，第 $3 ， 4$ 脚は細長または短 小である。特に雄の第 4 脚は甚だ小さい。雄は各脚端に 関節状の区分のある長い柄のついた肉盤を有している が，雌は第 $1 ， 2 ， 4$ 脚に雄と同じ肉盤をあち，第 3 脚 だけ肉盤を欠き， 3 本の剛毛を代りに有する。雄は尾端 に 2 個の突起すなわち腹葉をあち, これに 5 本の剛毛が 生えている。交尾は反対側に向って行われる（写真8)。 耳介内だけで生活史を繰り返しているので, 病巣から成 虫以外に多数の幼虫（脚が 3 対）や卵（卵円形で仔を含 んでいる）が採集される。

接着ダ二検査法：最初に，七ロテープ，両面テープ, ビニールテープについて取り扱いやすさを検討した。セ ロテープと両面テープは接着力は強かったが，しわが寄 ったり，互に貼り付いて離れにくいなどの欠点があっ た。ビニールテープにはこれらの欠点がなく扱いやすか ったので, 接着力の点では劣っていたが採用した。次に テープの色を無色透明, 白, 赤, 青, 黄の 5 種類につい て検討した。黄色がダ二の色（吸血した成虫赤色, その 他幼虫などは淡い青色またはわずかに青味を帯びた白 色）と非常に明膫に識別できた。以上の結果に基づき， ダニのスクリーニング法として下記の方法を考案し, 「接着ダ二検査法 (mite adhering test)」と命名した。 すなわち,

「黄色ビニールテープ（幅 $19 \mathrm{~mm}$, 日東電気社）を スライドグラスの長さに切り, 粘着面を表にして人指し 指で押え，人指し指の先端で耳甲介艇に密着させた後に 剝ぎ取る。これをスライドグラスに貼り付けて, 双眼解 剖顕微鏡下 $(\times 40)$ で, ダ二の成虫, 幼虫および卯の有 無を観察する（写真5一8）。」

本検査法によるダ二検出と肉眼所見の関係：全ウサギ で本検査法によりダ二の寄生の有無を調べた。同時に肉 眼的観察を行い，症状を一，十， H，卅の 4 段階(図 1 ) に分けた。結果は表 1 亿示す如くであった。肉眼所見が ＋以上のウサギでは100\%において, 本検査法によりダニ が検出された。+の例では，38匹中19匹（50\%）でダ二 が検出された。特に注目すべきととは肉眼所見一のウサ ギ20匹で，本検査法によりダ二の寄生を確認できたとと である。この結果は接着ダ二検査法を行い, 注意潹く肉 眼的観察すれば。本症を早期に発見でき, 治療予防の面 で非常に有利であることを示している。

接着ダ二検査陽性または肉眼所見十以上を耳疥癬症之 規定すると，当施設では 216 匹中75匹（34.7\%）が本症 にかかっていた（表 1)。

考察：Psoroptes 属のダニはウシ，ヒツジ，ヤギ，ウ マなどに寄生し痂皮を起し耳疥䬺症を起すととが知られ
Table 1. Comparison of the results between macroscopic observation and mite ndhering tesr

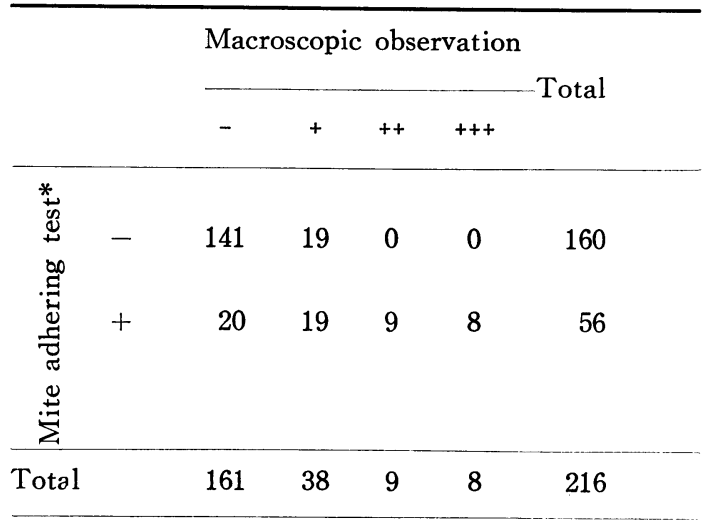

Proportion of rabbits diagnosed as ear canker $=75 / 216(34.7 \%)$

* - indicates the rabbits free from mites and + those infected with mites.

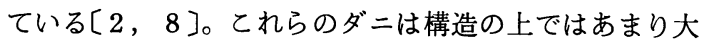
きな違いがない。Hering (1838) は，乙の属は P. equi 1 種のみとし, 他の動物に寄生するあのを亜種とみなし て, ウサギに寄生するあのを $P$. equi var. cuniculi と 命名している（2）。Furstenberg あこの属はP. communis 1 種とし，他を亜種としている[11]。これに対して Delafond（1959）は各動物種にダ二を独立した種とし， ウサギに寄生するすのを $P$. cuniculi と命名している [12]。分類学上の詳細な点は別として, 実験動物では動 物種ごとに独立した種とする方がわかりやすく，実際的 であると考えて，本実験で分離されたダ二を Psoroptes cuniculi（ウサギキュウセンヒゼンダ二）と同定した。

井上・野坂も本症の病巣加ら P. cuniculi を分離して いる[7]。当施設では業者から納入されるウサギを厳重 にチェックしているが，てのチェックでみつかった耳疥 瘯症の病巣からあこのダ二が採集された。さらに，山之 内製薬中央研究所で飼育繁殖中のウサギからあ P.cuniculi が分離されている[10]。乙れらのととを考慮する と, わが国では P. cuniculi が広く分布し, ウサギの耳 疥㿏症の原因となっていると思われる。

相当拡がった病巣からダニを採集することは容易で, 試みられている。しかし，ダニが肉眼的病巣を形成する 前に, ダ二の寄生の有無を確かめる方法は, 知る限りで は, 全くない。本研究で考案した接着ダ二検査法はこの 目的に適う最初の方法である。表 1 に示されているよう に, 肉眼的に発症が確認されなかった20匹のウサギでダ 二の寄生を証明できたととは特筆に值する。しかし，肉 眼所見十のウサギの半数において，ダニを検出できなか 
ったので, さらに改良の余地があろう。これらのダ二を 証明できなかった半数のウサギが本当にダニによる耳疥 癬症であったのかという疑問があるにしてあ, 注意深い 肉眼的観察とこの接着ダ二検査法の併用に本症を非常に 早期に発見でき，治療予防に大いに役立つと考えられ る。さらに, 本検査法は非常に簡単でかつ短時間ででき ウサギには全く危害を加えないので, ウサギ購入時の検 查などで広範囲に応用できる。

本研究で, 当施設では 3 割強のウサギが耳疥癬症にか かっていることがわかった。現在これらの動物の治療法 を研究中であるので，その結果を追って報告したい。

要約：当施設では過去数年にわたりウサギの耳疥䬺症 の蔓延に悩まされてきた。そこで, 本症の治療, 撲滅お よび予防法を確立するために一連の研究を始めた。本研 究では原因ダニの同定と簡単なダニのスクリーニング法 の確立を試み, 次の結果を得た。

1, 当施設のウサギの耳疥癖症は Psoroptes cuniculi (ウサギキュウセンヒゼンダニ) によるととがわかっ た。

2. 簡単なダニのスクリーニング法として「接着ダニ 検査法 (mite adhering test)」を考案した。この検査 法により，ダニが肉眼的病巣を形成する以前に，ダ二の 寄生の有無を調べるととができた。

3. 接着ダ二検査法と肉眼的観察の併用により, 本症 を非常に早期に発見できることを明らかにした。この併 用により当施設で飼育中のウサギ 216 匹中75匹 (34.7\%) が耳疥㿏症と診断された。

\section{謝 辞}

ダニの分類についてご助言，で批判いただいた当研究 所佐々学教授に厚くお礼申し上げる。また, 当施設の丸 山内一郎, 前原時司, 長沢由人諸氏ので援助に謝意を表 する。

\section{文}

献

[1] Adames, C. E. (1972). The rabbit. In The UFAW Handbook on the Care and Management of Laboratory Animals(4th ed.). UFAW, editor, Churchill Livingstone, Edinburg and London, 167-186.

[2] Baker, E. W., Evans, T. M., Gould, D. J., Hull, W. B., Keegan, H. I. (1956) A Manual of Parasitic Mites National Pest Control Association, Inc., New York, 139-141.

[3]藤原公策 (1970) 実験動物の病気, 実験動物学, 田嶋嘉雄編, 179-240。

[4]福井正信 (1965)。家畜病害虫としてのダ二類, 佐々学編, 東大出版会, 東京, 359-367。

[5]今泉清 (1956)。疾病, 医学研究動物実験法, 安東 洪次田嶋嘉雄編, 175-240。

[6] 井上廉 · 野坂大 (1950)。家兔の耳疥䬺症（いわ ゆる耳癄）とその治療について（下）, 獣医畜産 新報，48，695-697。

［7]井上廉·野坂大 (1950)。嫁兔の耳疥䬺症（いわ ゆる耳瘡）とその治療について（上）, 獣医畜産 新報, 48 , 623-625。

[8] 佐々学 (1965)。ヒゼンダ二類（無気門亜目一そ の 1 無気門上団), ダ二類, 佐々学編, 東大出版 会, 東京, 252-277。

[9]佐々学 · 三浦昭子 - 青木淳一 - 今村泰二 · 江原昭 三・伊戸泰博(1965), 採集法および実験法, ダ二 類, 佐々学編, 東大出版会, 東京, 28-44。

[10]鈴木弘 (1973), Personal communication.

[11]德永雅明 (1943), 医用昆虫学, 金原商店, 大阪 . 東京·京都, 1292-1298.

[12] Zumpt, F., Audy, J. R., Grand, J., Lawrence, R. F., Theiler, G., Till W. M., VercammenGrandjean, G. P. (1961), The Arthropod Parasites of Vertebrates in Africa South of the Sahara. G. M. Horne (PTY.) LTD, Johannesburg, 331-333. 